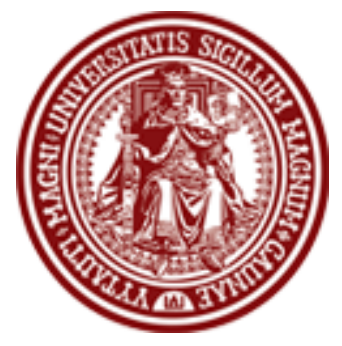

BALTIC JOURNAL OF LAW \& POLITICS

VOLUME 5, NUMBER 1 (2012)

ISSN 2029-0454

http://www.versita.com/bjlp

Cit.: Baltic Journal of Law \& Politics 5:1 (2012): 99-116

DOI: $10.2478 / v 10076-012-0005-z$

\title{
THE EUROPEAN COURT OF HUMAN RIGHTS: BRINGING TOGETHER LEGAL SYSTEMS
}

\author{
Alina Cherviatsova \\ Associate Professor; Vice-Dean for International Relations \\ Faculty of Law, V.N. Karazin Kharkiv National University (Ukraine) \\ Contact information \\ Address: Svobodi sq. 6, Kharkiv 61022, Ukraine \\ Phone: + 3807075069 \\ E-mail address: alinaCH@ukr.net
}

Received: April 12, 2012; reviews: 2; accepted: June 12, 2012.

\begin{abstract}
Since its creation in 1959, the European Court of Human Rights has had a direct impact on the national systems of its members. One of the main features of the European Court of Human Rights is that during its evolution and decision-making processes it has brought together legal systems in the light of human rights established in the European Convention on Human Rights. The present work discusses the role that the European Court of Human Rights has played in this matter by examining its development during its six decades of work, analyzing the methodology, techniques and theories that it uses to interpret the European Convention on Human Rights, and describing the implementation and enforcement of the European Court's decisions if and when they implied a change of member state home legislation.
\end{abstract}

\section{KEYWORDS}

European Convention on Human Rights, European Court of Human Rights, legal system, European Court's case law, implementation of the European Court's judgments, interpretation of the European Convention 


\section{INTRODUCTION}

The European Court of Human Rights was set under the European Convention on Human Rights (formally the European Convention for the Protection of Human Rights and Fundamental Freedoms). The Convention mechanism is considered a unique phenomenon in international law. Since its creation, this international Court has influenced the domestic law of many states in Europe. Likewise, during its evolution the Court has consolidated two important features: the granting to individuals, whose rights are denied, direct access to an international organ capable of protecting them; and a judicial body on the international level, competent to assess the behavior of national governments towards the compliance of human rights. In practice, this also means that the European Court may declare a breach of state's international obligations, even if, in terms of national law, the acts of local authorities were legitimate. Evidently, these features of the European Court of Human Rights had to turn it into a living mechanism capable of responding to the challenges of the globalization process, because it has created fundamental standards that are spread throughout the domestic legislation of the European states. As a result, the European Court has unified different legal cultures and can be described as a "quasi-constitutional court for the whole Europe"1.

This article analyzes how the European Court of Human Rights brings together the legal systems and domestic law of states, by focusing first on the creation and then on the evolution of this Court: from the traditional positivist theory of international law, which limited the rights of privates to participate in an international legal process, to the current state after Protocols 11 and 14, which granted the court the exclusive jurisdiction to receive individual applications, and to declare the breach of international obligations. The second part of this article will examine the key developments that the court has created in order to construct a true "European Human Rights Law"; above all, the focus falls on the so-called "theory of autonomous concepts" or "theory of autonomous interpretation". This theory allows the Court to evaluate domestic legislation, by independently interpreting the terms of the European Convention on Human Rights; therefore, giving no space to states of eluding international obligations. Finally, the last part of the article is devoted to the implementation of the European Court's decisions and the incorporation of the European standards on human rights created by the Court into the national legislation.

\footnotetext{
${ }^{1}$ Rolv Ryssdal, "The Coming Age of the European Convention on Human Rights," European Human Rights Law Review 1 (1996): 22.
} 
Until recently there were no guarantees of human rights at the level of international law. The prevalent philosophy of international law in the nineteenth and early twentieth centuries maintained that international law was law for states alone. Hence, it was impossible even to assume the existence of international legal rights which an individual could assert against state. ${ }^{2}$ In eighth edition of Oppenheim's classic international law treatise published in 1955, the traditional positivistic doctrine says:

Since the Law of nations is primarily a law between States, States are, to that extend, the only subjects of the Law of Nations... But what is the normal position of individuals in International Law, if they are not regularly subjects thereof? The answer can only be that, generally speaking, they are objects of the Law of Nations. $^{3}$

The traditional positivist theory of international law dramatically limited the rights of the private person to participate in an international legal process. Whether or not a violation of individual rights was to become the subject of an international claim depended entirely on the discretionary power of the individual's protecting state. Thus, if the individual's own state violated human rights, neither state nor individual could protect them at the level of international law.

The transformation of the substantive norms of human rights law from the national to international level was made in 1948 in the Universal Declaration of Human Rights. ${ }^{4}$ Humanity had to see the horrors of two world wars to understand that respect for human rights should be one of the basic principles of international law. The emergence of international human rights law in the Universal Declaration has been described as the most "radical development in the whole history of international law" since it so rapidly established individuals as well as states as subject of international law. ${ }^{5}$ The Universal Declaration had special meaning for those who had witnessed the awful abuses of human rights in Nazi-occupied Europe. For the Europeans, human rights became an important priority.

On November 4, 1950 the European Convention for the Protection of Human Rights and Fundamental Freedoms was signed. It came into force three years later, in 1953, after its ratification by eight countries: Denmark, the Federal Republic of Germany, Iceland, Ireland, Luxembourg, Norway, Sweden, and the United Kingdom. The European Convention drafters came with the rule: "no remedies, no

\footnotetext{
${ }^{2}$ Mark W. Janis and Richard S. Kay, European Human Rights Law (Connecticut: University of Connecticut Law School Foundation Press, 1990), p. 9.

${ }^{3}$ L. Oppenheim, International Law, $8^{\text {th }}$ ed. (Lauterpacht, 1955), p. 1955.

4 J. P. Humphrey, "The Universal Declaration of Human Rights: Its History, Impact and Juridical Character": 21; in: B. G. Ramcharan, ed., Human Rights: Thirty Years After the Universal Declaration (Dordrecht: Martinus Nijhoff, 1979).

5 J. P. Humphrey, "The revolution in International Law on Human Rights", Human Rights Law Journal 4 (1974-75): 205, 208-209.
} 
rights". As a result the European Convention not only proclaims fundamental rights and freedoms but has created the international mechanisms for their protection the European Commission of Human Rights and the European Court of Human Rights. ${ }^{6}$ The European system of human rights protection is considered to be a unique phenomenon in International Law. It has two important innovations: the granting to individuals (whose rights are denied) access to the international organ capable of protecting them; and the institution of a judicial body on an international level competent to render judgments on national governments.

It should be noted that not all of the European countries that participated in the drafting of the European Convention endorsed the idea of creating the European Court and the right of individual petition: seven countries - Denmark, Greece, Norway, the Netherlands, the United Kingdom, Sweden and Turkey - were opposed to it, while four countries - Belgium, France, Ireland and Italy - were in favor of it. ${ }^{7}$ As a compromise, supported by eight countries - Belgium, France, Greece Ireland, Italy Luxembourg, Sweden and Turkey, - and opposed by two - the Netherlands and the United Kingdom - Sweden proposed the creation of an optional Court. In 1950 states' fear that the right of individual petition might easily violate the principle of state sovereignty was too strong. As a result it was decided to make both jurisdiction of the European Court and the right of individual petition optional.

The heart of the European Convention, in its original version, contained two optional clauses providing the crucial parts of the system's human rights enforcement machinery: Article 25, giving individuals as well as states the right to petition the European Commission of Human Rights, and Article 46, giving the European Court of Human Rights jurisdiction to hear and try cases already reported upon by the Commission. Over time, one-by-one the nations of the Council of Europe have consented to the two optional provisions. As of January 1, 1990, all twenty-two member-states of the Council of Europe, who were parties to the European Convention, have accepted the Article 25 right of individual petition and the Article 46 jurisdiction of the Court.

\section{EVOLUTION OF THE EUROPEAN COURT OF HUMAN RIGHTS}

The European Convention is now more than sixty years old. Each of the six decades of the European Convention had its own distinctive problem. The 1950s had to deal with institutional development but had little actual problem with

\footnotetext{
${ }^{6}$ Since 1998, the European Court of Human Rights has had exclusive jurisdiction to receive individual applications.

7 Council of Europe, Collected edition of the "Travaux préparatoires" of the European Convention on Human Rights. Vol.2. Consultative Assembly, Second Session of the Committee of Ministers, Standing Committee of the Assembly (10 August - 18 November 1949) (The Hague: Martinus Nijhoff, 1975), p. 248.
} 
interpretation and case law. This is not particularly surprising. During the first ten years the Conventional system could not create case law because it had almost no lodged applications. The Convention came into force in 1953. In 1955 the Commission was granted the right to hear individual petitions against the states. The European Court was constituted in 1958. Only in June, 1956, was an application declared admissible by the Commission (by Greece against the UK respecting Cyprus). Altogether there were only five applications (two by a government and three by individuals). No case was heard by the European Court. ${ }^{8}$

The 1960s saw both triumph and failure in the Conventional system. There were fifty-four applications admitted by the European Commission (five government, forty-nine individual) and the European Court made its first ten decisions. However, in 1969, after adverse reports by the European Commission, Greece denounced the European Convention on Human Rights. This reduced the total membership in the system from sixteen to fifteen at the end of the decade. The number of states accepting the rights of individual petition had grown to eleven. The same number (thought not always the same states) accepted the jurisdiction of the European Court. ${ }^{9}$

The 1970s witnessed a progressive development of the European system. Greece rejoined the Convention in 1974. By the end of the decade about twenty countries had gained membership in the European Council, and fourteen of them had accepted the right of individual petition. One hundred sixty-eight applications (five government, one hundred sixty-three individual) were deemed admissible by the European Commission. Twenty-four cases were decided by the Court. ${ }^{10}$

The 1980s saw an explosion of activity in the European conventional system. By the end of 1989, twenty-two of the twenty-three states members of the Council of Europe (all except Finland) were party to the Convention. All twenty-two ratifying states have accepted the right of individual petition and have consented to the jurisdiction of the European Court. ${ }^{11}$ Thus, the European system's development indicates its success that may be manifested in many ways, both in the effect it has had on domestic law and the increasing number of the applications being lodged before the European Court. ${ }^{12}$

\footnotetext{
8 Council of Europe, Directorate of Human Rights, Yearbook of the European Commission on Human Rights (1958-1959) (The Hague: Martinus Nijhoff, 1960).

9 Council of Europe, Directorate of Human Rights, Yearbook of the European Commission on Human Rights (1969) (Brill Academic Pub, 1971).

${ }_{10}$ Council of Europe, Directorate of Human Rights, Yearbook of the European Commission on Human Rights (1979) (The Hague: Martinus Nijhoff, 1980).

${ }^{11}$ Council of Europe, Directorate of Human Rights, Yearbook of the European Commission on Human Rights (1989) (The Hague: Martinus Nijhoff, 1990).

12 George Letsas, A Theory of Interpretation of the Convention on Human Rights (Oxford University Press, 2007), p. 2.
} 
In the 1990s the conventional institutes faced the problem of their effectiveness. First, the European Court became a "victim of its own success"13, having difficulty managing the ever-increasing caseload. It was caused partly by the increased awareness of the right of individual petition within Contracting States and partly by the enlargement of Europe's legal borders to include Eastern Europe following the collapse of the Eastern block. To solve the problem of the caseload, the system was reformed in 1998. The first reform of the European mechanism for human rights protection under Protocol 11 was made possible by a new understanding of human rights. From 1950s to the end of 1980s the states revised their attitude toward the relationship between two fundamental principles: the universality of human rights on one hand and state sovereignty on the other. The European states concluded that the first value (human rights) is more important. Since 1998, with the Protocol 11 entering into force, the European Court has had exclusive jurisdiction to receive individual applications; the recognition of the right to individual petition before the European Court is compulsory for all Member States. Thus, in accordance with the Protocol 11 an individual got direct access to the European Court, whose judgments are binding for the States.

The first decade of the twenty-first century showed that the problem of the European Court's effectiveness remains in force. Membership in the Council of Europe doubled within twenty years, from 23 in 1990, to 47 in 2010. This development only added to the problems that the European Court was facing before. In 1999, the first full year of the Protocol 11 reforms, the European Court received 8,400 applications and produced 177 judgments on the merits of cases before it. In the course of 2010 the European Court received 61,300 new applications. Some $90 \%$ of the applications to the Court are, on examination, found to be clearly inadmissible or ill-founded applications. Still the European Court managed in the course of 2010 to process over 41,000 applications and to produce 1,500 substantive judgments on the merits. But by the end of 2010 the backlog of unprocessed applications awaiting consideration by the court had reached approximately 140,000 applications, with the queue increasing in the course of 2010 by more than 1,600 applications per month. ${ }^{14}$ The pressure caused by the sheer number of applications has meant the build-up of long delays within the system, which is ironic, given that the European Court is often called upon to judge whether court procedures in national courts have been conducted "within reasonable time".

\footnotetext{
13 M.-B. Dembour, "Finishing Off" Cases: The radical Solution to the Problem of the Expanding ECtHR Caseload," European Human Rights Law Review (2002): 604.

${ }_{14}$ Aidan O'Neill, "Reform of Strasbourg Court: a modest proposal," UK Human Rights Blog //

http://ukhumanrightsblog.com/2011/03/28/reform-of-strasbourg-court-a-modest-proposal-aidan-oneill$\mathrm{qc} /$.
} 
The European Court's excessive workload is due to two factors in particular: the first is processing a great number of applications that are declared inadmissible (more than $90 \%$ on which a decision is made); the second one is processing applications related to structural issues, in which the European Court has already delivered judgments finding a violation of the European Convention, and where a well established case law exists. These applications, called repetitive cases, represent around $60 \%$ of the judgments of the European Court every year. ${ }^{15}$

The prospect of a continuing increase in the workload of the European Court led to the conclusion that a reform was necessary if the system was to be preserved. The plan for the European Court reform started in 2001, on the basis of proposals from the Steering Committee for Human Rights. In 2004 Protocol 14 was opened for signature to member States. The document is aimed to speed up the handling of cases improving the efficiency of the European Court. The ultimate aim of the reform under the Protocol 14 is to enable the Court to concentrate on those cases that raise important human rights issues.

The ratification of Protocol 14 faced the problem that, in order to come into force, it needed the approval of all the members. This condition did not occur because the Russian Federation was blocking it. After this, it became obvious that the procedure for making reforms of the European Court had itself to be changed and made more flexible. At a seminar in 2008 that celebrated the tenth anniversary of the entry into force of Protocol 11 to the European Convention, participants agreed that in order to save the right of the individual to petition the European Court, there was the need to reform it, even without Protocol 14. In April 2009, the Parliamentary Assembly of the Council of Europe issued Protocol 14-bis to the European Convention. In general, Protocol 14-bis has the same aim and rules (regarding the speed of handling cases before the European Court) as Protocol 14 did. The major difference is that the rules of Protocol 14-bis enter into force roughly three months after the date on which three High Contracting Parties to the European Convention have agreed to be bound by the Protocol. In contrast to Protocol 14, it has no requirement that all 47 member states must ratify it, but it will be applicable only for those member states that do ratify it. As a result, any deliberate attempt to block the reforms by Russia (or any state) will no longer have its intended effect. Finally, Russia ratified Protocol 14 on January 15, 2010. It entered into force six months later, on June 1, 2010, and beginning the longawaited reform of the European Court. ${ }^{16}$

${ }^{15}$ Council of Europe, Protocol 14. The reform of the European Court of Human Rights (Factsheet, 2010), p. 2.

${ }_{16}$ Anton Burkov, "Russia and Euroepan Court of Human Rights: Reform of the Court and of Russian judicial practice?" Foreign and Security Policy, CEPS Commentaries (May, 2010): 1-2 // 
Protocol 14 introduces changes in three main areas: reinforcement of the European Court's filtering capacity to deal with clearly inadmissible applications; a new admissibility criterion concerning cases in which the applicant has not suffered a significant disadvantage; measures for dealing more efficiently with repetitive cases. These features of Protocol 14 significantly improve the efficiency of the Court, but they did not solve its backlog of applications. Thus, the reform of the European Convention system under Protocol 14 is not the last one.

As we can see, the European Court of Human Rights is a living mechanism capable of responding to challenges. As a result, the European Court can be described as a "quasi-constitutional court for the whole of Europe" which has created "European Human Rights Law".

Article 1 of the European Convention formulates the obligation of the participating states to respect human rights: "The High Contracting Parties shall secure to everyone within their jurisdiction the rights and freedoms defined in ... (the) Convention". This means that the Contracting States have to create favorable conditions (on the level of their national legislation and legal practice) for the fulfillment of conventional rights and freedoms. It is extremely significant that state obligations concern not only their citizens but to all individuals within its jurisdiction. A Contracting State has to guarantee the fulfillment of these rights to its citizens, foreigners and stateless persons. Thus, the scope of conventional rights and freedoms as well as the context of state obligations do not depend on citizenship. The fundamental rights and freedoms should be guaranteed to everyone as these are human rights.

The observance of obligations under the Convention undertaken by the states is entrusted to the European Court of Human Rights (Article 19 of the Convention). The European Court has two main mechanisms to perform: the first one is to consider individual complains, brought before the Court by persons, nongovernmental organizations or groups of individuals; and the second one is to consider intergovernmental complaints. Another feature of the European Court's jurisdiction is that it considers complaints against violations of the Convention. This means that the European Court may declare a breach of a state's international obligations, even if in terms of national law the acts of local authorities were legitimate. Thus, the rights and freedoms proclaimed by the Convention require States to review existing national legislation and legal practice.

http://www.ceps.eu/book/russia-and-european-court-human-rights-reform-court-and-russian-judicialpractice. 


\section{THEORIES OF INTERPRETATION}

The European Court has at least three very important theories which help it to bring together the legal systems of the Contracting States and which underline the European Court's case law. These are: the so-called "theory of European public order"; the "theory of evaluative or dynamic interpretation"; and the "theory of autonomous concepts (autonomous interpretation)"17.

First, the theory of European public order was produced by the European Court through considering interstates cases. In accordance with the theory of European public order, the European Convention is not only a document that establishes the mutual rights and obligations of the Contracting States, but it is a document under which a special public order of European human rights protection is created. This approach was used by the European Court in the case Austria v. Italy. In this case Italy argued that the complaint filed by Austria could not be considered because it dealt with circumstances that arose before Austria had joined the European Convention. The European Commission rejected the objection of Italy, noting that:

The obligation undertaken by the High Contracting Parties in the Convention are essentially of an objective character, being designed rather to protect the fundamental rights of individual human beings from infringement by any of the High Contracting Parties than to create subjective and reciprocal rights for the High Contracting Parties themselves. ${ }^{18}$

In the case of Cyprus $v$. Turkey the respondent State denied the jurisdiction of the European Commission and European Court to consider the complaint, arguing that it was filed by the state, which Turkey did not recognize. The European Commission declared this application admissible, because, in its view, the nonrecognition of one state by another does not affect European Commission's jurisdiction, as the European Convention establishes guarantees to protect European public order of human rights protection. In its resolution the European Commission recalls that:

A system of collective protection of human rights, as established by the Convention, requires, in order to be effective, the co-operation with the Commission of all High Contracting States concerned in a case ... . The Commission cannot accept the respondent Government's statement, that it does not recognize the applicant Government as the Government of Cyprus, as a

17 See Vladimir I. Manukijan, Evropeiskii sud po pravam cheloveka: pravo, precedenti, komentarii. Nauchno-prakticheskoe posobie (Kiev: Istina, 2007), p. 21-33 [in Russian]; Stanislav Shevchuk, Porivnialne precedentne pravo z prav liudini (Kyiv: Referat, 2002), p. 83-100 [in Ukrainian]; George Letsas, supra note 12, p. 61-79.

18 Austria v. Italy, European Commission of Human Rights, Decision of January 11, 1961, App. No. $788 / 60$, Yearbook 4, § 140. 
ground which could absolve Turkey from its obligation to co-operate with the Commission in the present proceedings ... .

The Convention establishes a system of collective enforcement and... an application brought under Article 24 does not of itself envisage any direct rights or obligations between the High Contracting Parties concerned ... .

The Commission considers further that to accept that a Government may void 'collective enforcement' of the Convention under Article 24, by asserting that they do not recognize the Government of the applicant State, would defeat the purpose of the Convention. ${ }^{19}$

However, the evaluative interpretation theory was made in the Golder case, which is undoubtedly one of the most important cases in the history of the European Court. It had wide discussion of the rules of interpretation; in particular, in this case debates arose between originalists and non-originalists about the problem of "unenumerated rights". These are rights that are not expressly mentioned in the text but it is proposed that they should be "read into" it. In Goder it was right to access to court under the article 6 of the European Convention. The respondent state, the United Kingdom, argued that the European Convention says nothing about a right to access the court. As there is no explicit provision there is no obligation of the state to ensure that everyone gets to have a case heard, but if a person gets to the court she or he must be given a fair trial.

In its judgment the European Court made the hypothetical point that if the right to access to the court is not guaranteed by the European Convention, states " ... could, without acting in breach of that text, do away with its courts, or take away their jurisdiction to determine certain classes of civil actions and entrust it to organs dependent on the Government ..."20. Such assumptions, the European Court held, are "indissociable from a danger of arbitrary power" and would have serious consequences which are repugnant to the principle of the rule of law.

Thus, the European Court concluded that:

The right of access constitutes an element which is inherent in the right stated by Article 6 para. 1 (art. 6-1)» and stressed that «this is not an extensive interpretation forcing new obligations on the Contracting States: it is based on the very terms of the first sentence of Article 6 para. 1 (art. 6-1) read in its context and having regard to the object and purpose of the Convention. ${ }^{21}$

Commenting on the Golder judgment, George Letsas explains that:

19 Cyprus v. Turkey, European Commission of Human Rights, Resolution DH (92) 12 of April 2, 1992, App. No. 8007/77, § 39-43//

http://www.kypros.org/Occupied_Cyprus/Cyprus_v_Turkey_1993_15_EHRR_509_Eur_Comm_HR.htm.

20 Golder v. UK, European Court of Human Rights, Judgment of February 21, 1975, App. No. 4451/70,

$\S 36 / / \mathrm{http}: / /$ hudoc.echr.coe.int/sites/eng/pages/search.aspx?i=001-57496.

${ }_{21}$ Ibid., $\S 36$. 
This was an important line of reasoning. The Court not only rejected the view that lack of an explicit provision in the text constitutes an obstacle for granting an unenumerated right. It also stressed that the question whether to grant an unenumerated right is not a question of whether we should stick to the actual text or extend its meaning through interpretation. For the majority of judges in Golder did not think they added the right to access to court to art $6 \mathrm{ECHR}$; they insisted that by recognizing the right to access to court, they followed an interpretation based on 'the very terms' of the first sentence of art 6 para 1 and did not force any 'new' obligation on the Contracting States. On the contrary, they thought that fidelity to art $6 \mathrm{ECHR}$ demanded granting this right. 'This is what the text says', the could have said, 'these are its very terms'. ${ }^{22}$

The third theory, the theory of autonomous interpretation, is a powerful tool that allows the European Court to control national legislation and legal practices of the Contracting States. In one of the first decisions on the autonomous concepts, the European Commission noted that the Conventional terms, in particular, "criminal charge" and "civil rights and obligations", "cannot be constructed as a mere reference to the domestic law of the High Contracting Party concerned but relate to an autonomous concept which must be interpreted independently, even though the general principals of the High Contracting Parties must necessary be taken into consideration in any such interpretation"23.

In other words, any conventional term can have two meanings - under the Convention and under domestic law. Thus, it implies a certain asymmetry, tension or even contradiction between the Convention and national legislation. At this rate, the provisions of national legislation should be considered when interpreting conventional norms; however, they are not decisive. The Commission granted that there is a lack of correspondence between the two and it made a claim about their relation: domestic law classification is relevant but not decisive for the meaning of the terms of the Convention. This is what the adjective "autonomous" stands for: the terms of the Convention enjoy a status of semantic independence - their meaning is not to be equated with the meaning that these very same terms possess in domestic law. For example, "conventional criminal charge" does not necessarily mean "domestic-law criminal charge". Independent interpretation of the Convention recognizes semantic independence - i.e., the meaning of the Convention may differ from what the concept is in the national legal system.

Later, in the Engel case, the European Court developed the concept of autonomous interpretation of the Convention. ${ }^{24}$ In 1971 , Cornelis Engel and four

\footnotetext{
22 George Letsas, supra note 12 , p. 63.

23 Twenty-One Detained persons v. Germany, European Court of Human Rights, Decision of April 6, 1968, Collection 27, § 4.

${ }^{24}$ Engel and Others $v$. the Netherlands, European Court of Human Rights, Judgment of June 8, 1976, App. No. 5100/71,5101/71,5102/71,5354/72, 5370/72, Series A, no 22 //
} 
other conscript soldiers serving in the Netherlands armed forces applied to the European Court, claiming a violation in the imposition penalty by military court for disciplinary offences. The applicants complained that the penalty issued to them constituted deprivation of liberty contrary to Article 5 of the European Convention (the right to liberty and security) and that the proceedings before the military authorities did not satisfy the requirements of Article 6 (right to fair trial). The government of the Netherlands responded that Article 6 was not violated, because the proceedings against the applicants involved neither "civil rights and obligations" nor "criminals charged"; these proceedings were, under domestic law, strictly disciplinary and therefore that was not at all applicable ${ }^{25}$. In other words, the guarantees of Article 6 do not extend to disciplinary charges but are limited to criminal charges and the "determination of civil rights".

In its judgment, the European Court agreed that there is a distinction between disciplinary proceedings and criminal proceedings and this distinction is reflected in a long-standing practice in all Contracting States. Thus, the European Court acknowledged that there are two distinct concepts in the domestic law of all Contracting States: the concept of "disciplinary charge" and the concept of "criminal charge". Bearing in mind the distinctness of the two concepts in legislation, it is natural to assume, as the respondent state did, that the guarantees of Article 6 do not extend to disciplinary charges but are limited to criminal charges and the "determination of civil rights and obligations". The European Court considered this assumption and asked: "Does article 6 cease to be applicable just because the competent organs of a Contracting State classify as disciplinary an act or omission and the proceedings it takes against the author, or does it, on the contrary, apply in certain cases notwithstanding this classification?"26

The European Court expressed the fear that some acts or omission may be classified by the Contracting States (either internationally, or by oversight) as disciplinary offence in a way that escapes the guarantees of Article 6: "If the Contracting States were able at their discretion to classify an offence as disciplinary instead of criminal... the operation of the fundamental clauses of articles 6 and 7 would be subordinated to their sovereign will"27.

As a means to prevent Contracting States from circumventing the Convention guarantees in this way, the European Court created the theory of autonomous concepts or autonomous interpretation. Since the Engel case, the European Court has developed this theory to make it a significant doctrine of its jurisprudence.

http://hudoc.echr.coe.int/sites/eng/pages/search.aspx?i=001-57479.

${ }^{25}$ Article 6 reads as follows: "In the determination of his civil rights and obligations or of any criminal charge against him, everyone is entitle to a fair and public hearing within a reasonable time by an independent and impartial tribunal established by law".

${ }^{26}$ Engel and Others $v$ the Netherlands, supra note $24, \S 80$. 
Using this approach, it has characterized as autonomous a significant number of terms and notions that figure in the Convention: criminal charge, civil rights and obligation, possession, association, victim, civil servant, lawful detention, home, etc. In its decision, twenty years after Engel, the Court more clearly says that "definition in national law has only relative value and constitutes no more than starting point" and that legal notions "must be interpreted as having autonomous meaning in the context of the Convention and not on the basis of their meaning in domestic law"28.

Autonomous interpretation allows the European Court to assess domestic legislation in terms of its compliance with the Convention provisions and counter the possibility that the Counteracting States will try to circumvent the Convention guarantees. In order to do this, the European Court concedes the possibility of an asymmetry between the Convention and domestic meaning: what the respondent state's law means by a legal notion is not the same as what the Convention means by the same term. This enabled the Court to examine whether a situation that respondent state classifies as lawful does not violate the Convention.

The theory of autonomous interpretation may be considered a result of the fact that the European Court adjudicates on cases coming from different legal systems. It is natural that there are some differences as to how legal terms and notions are understood or classified in each domestic law. But, from the other side, the Contracting Parties had to share some legal concepts in order to draft the Convention. Moreover, they established international instruments, the main aim of which is to ensure the Convention guarantees and to coordinate different legal systems. Hence, since conformity to the classification of one's domestic law would only constitute a violation of the classification of some other's domestic law, the departure from domestic definition is unavoidable. The European Court, on this account, must necessarily have some discretion to legislate in these borderline cases and secure the harmonization of national law. ${ }^{29}$

\section{IMPLEMENTATION OF THE EUROPEAN COURT'S DECISIONS}

The European Court has extensive powers. But, nevertheless, the European Court is not a court of appeal for the whole of Europe. It cannot invalidate or cancel the decisions of national courts; ${ }^{30}$ but it can establish a violation of the Convention

\footnotetext{
27 Ibid., $\S 82$.

28 J. J. v. Netherlands, European Court of Human Rights, Judgment of March 27, 1998, App. No. 9/1997/793/994 // http://hudoc.echr.coe.int/sites/eng/pages/search.aspx?i=001-58147.

29 George Letsas, supra note 12 , p. 49.

30 In some countries such as Belgium and the Netherlands, the internal legislation recognizes the European Court's judgments as a ground to reconsider all decisions taken by local courts in the particular case.
} 
and award, if necessary, fair compensation or just satisfaction for victims. The context of the interpretation of the terms, just satisfaction, means compensation for material and moral damage to a person by violation of the European Convention. Thus, the execution of the European Court's decisions provides for the payment of reimbursement to the applicants. However, the payment of compensation does not release the states from the obligation to review the national legislation and practice to bring them into conformity with the European standards.

It can be concluded that a finding of violations by the European Court requires the adoption by the respondent state of different measures - individual measures to put an end to the violations and erase their consequences, so as to achieve as far as possible restitutio in integrum, and, more difficult and more important, general measures preventing similar violations. To prevent similar violation in the future the state has to change its national legislation and legal practice. The Contracting Parties have to do this, because the European Court's decisions have a nature of precedent.

Defending conventional human rights and finding a state guilty in their violation, the European Court sets a precedent for itself according to which certain domestic legislation and practice are inconsistent with the Convention guarantees. A precedent created by the European Court is a model for its future decisions. Thus, if the state does not change its legislation and legal practice to bring them in balance with the Convention, the European Court will establish a violation of the human rights each times considering similar cases. Ideally, the Contracting Parties should take into account the European Court's decisions in order to change their internal laws, even in case when they are not a party in a process. That means that the state, to improve its legislation and legal practice, should not wait until the European Court renders a decision against it.

Statistics on execution of the European Court's judgments show that there are usually no problems with "just satisfaction". The states pay out compensation in time; however the enforcement of specific (individual) measures for the benefit of the victim faces difficulties. For instance, the European Court often decides that state authorities have to expunge a person's previous convictions and/or restore his or her rights. From the juridical point of view one of the most interesting individual measures taken during the enforcement of the European Court's judgments is the rehearing of a case by a domestic court. But the domestic court is competent to rehear a case only if this power was given to it by national legislation.

Every year the European Court of Human Rights hears applications which are analogous to those which have been already judged by this Court and in which violations of the Convention have been found. That is why the most serious problem connected with the enforcement of the European Court's judgments 
concerns general measures to be taken by the states in order to prevent further violations of rights and freedoms guaranteed by the European Convention. For example, a great number of applicants from Russia, Turkey and Ukraine had similar violations which tend to recur periodically and involve plenty of people. Cases from these countries are often called clone-cases, meaning analogous violations. The states are more ready to pay compensation to the applicants than to change the legislation.

One of the brightest examples of significant changes in the domestic legislation caused by the European Court's decision, that also demonstrates their precedent nature, is Bulgaria's executing of the Assenov judgment. ${ }^{31}$ In Assenov, the European Court, inter alia, dealt with the guarantees of the right to liberty and security of person. In accordance with article 5(1) of the Convention any arrest must be carried out in accordance with a procedure prescribed by law and must be "lawful". This provision should be read in connection with article 5(3): "Everyone arrested or detained... shall be brought promptly before a judge or other officer authorized by law to exercise judicial power and shall be entitled to trial within a reasonable time or to release pending trial ... ."

The national authorities are faced with two tasks under Article 5(3); first to ensure that detention at any stage of the pre-trial period is necessary in any given case, and second to ensure that the investigation is conducted with due diligence to ensure that the accused does not spend an excessive amount of time in pre-trial detention. The notion "other officer authorized by law" is co-terminus with "competent legal authority" (article $5(1)(c))^{32}$. Thus the tribunal must be independent and impartial, and must have power to make a binding legal decision ordering release. In the context of these notions a "prosecutor" is regarded to be unable to possess the requisite independence and impartiality.

Before Assenov, there were some Bulgarian cases where the European Court declared violations of article 5 in regard of the prosecutor. In Assenov (1998), the European Court summed up its position as follows:

The officer must be independent of the executive and the parties. In this respect, objective appearances at the time of the decision on detention are material; if it appears that at that time the 'officer' may later intervene in subsequent criminal proceedings on behalf of the prosecuting authority, his independence and impartiality may be open to doubt. The 'officer' must hear the

\footnotetext{
31 Assenov v. Bulgaria, European Court of Human Rights, Judgment of October 28, 1998, App. No. 24760/94 // http://hudoc.echr.coe.int/sites/eng/pages/search.aspx?i=001-58261.

32 Article 5(1) (c) says: "No one shall be deprived of his liberty save in the following cases and in accordance with a procedure prescribed by law: ...(c) the lawful arrest or detention of a person effected for the purpose of bringing him before the competent legal authority of reasonable suspicion of having committed and offence or when it is reasonably considered necessary to prevent his committing an offence or fleeing after having done so ...."
} 
individual brought before him in person and review by reference to legal criteria, whether or not the detention is justified. If it is not so justified, the officer must have the power to make a binding order for the detainee's release..$^{33}$

As a result of Assenov and other cases against Bulgaria, the new Bulgarian Criminal Procedure Code declares as the main principle of the Convention that is solely the court that decides on the detention. Thus, to fulfill the European Court's decisions under article 5 of the Convention, Bulgaria had to reform its criminal procedure legislation and law-enforcement system.

\section{CONCLUSIONS}

The activity of the European Court brings different legal systems of the European countries together due to the following factors:

- The European Court is an international judicial body of exceptional authority, whose judgments are binding for the 47 European states;

- The European Court deals not with citizens but human rights, which are universal (consequently, in order to be protected under the provisions of the Convention it is not necessary to have the citizenship of a Contracting State);

- The European Court makes decisions concerning the European Convention that helps to control national legislation;

- The European Court's decisions create legal precedents for future cases.

\section{BIBLIOGRAPHY}

1. Assenov v. Bulgaria. European Court of Human Rights. Judgment of October 28, 1998. App. No. 24760/94 // http://hudoc.echr.coe.int/sites/eng/pages/search.aspx?i=001-58261.

2. Austria v. Italy. European Commission of Human Rights. Decision of January 11, 1961. App. No. 788/60. Yearbook 4, p. 116.

3. Burkov, Anton. "Russia and European Court of Human Rights: Reform of the Court and of Russian judicial practice?". Foreign and Security Policy, CEPS Commentaries (May, 2010): 1-3 // http://www.ceps.eu/book/russia-and-european-court-human-rights-reformcourt-and-russian-judicial-practice.

4. Council of Europe. Collected edition of the "Travaux préparatoires" of the European Convention on Human Rights. Vol.2. Consultative Assembly, Second Session of the Committee of Ministers, Standing Committee of the Assembly (10 August - 18 November 1949). The Hague: Martinus Nijhoff, 1975.

\footnotetext{
${ }^{33}$ Assenov v. Bulgaria, supra note $31, \S 146$.
} 
5. Council of Europe, Directorate of Human Rights. Yearbook of the European Commission on Human Rights (1958-1959). The Hague: Martinus Nijhoff, 1960.

6. Council of Europe, Directorate of Human Rights. Yearbook of the European Commission on Human Rights (1969). Brill Academic Pub, 1971.

7. Council of Europe, Directorate of Human Rights. Yearbook of the European Commission on Human Rights (1979). The Hague: Martinus Nijhoff, 1980.

8. Council of Europe, Directorate of Human Rights. Yearbook of the European Commission on Human Rights (1989). The Hague: Martinus Nijhoff, 1990.

9. Council of Europe. Protocol 14. The reform of the European Court of Human Rights. Factsheet, 2010.

10. Cyprus v. Turkey. European Commission of Human Rights. Resolution DH (92) 12 of April 2, 1992. App. No. 8007/77 // http://www.kypros.org/Occupied_Cyprus/Cyprus_v_Turkey_1993_15_EHRR_ 509_Eur_Comm_HR.htm.

11. Dembour, M.-B. "'Finishing Off' Cases: The radical Solution to the Problem of the Expanding ECtHR Caseload." European Human Rights Law Review 5 (2002): 604-623.

12. Engel and Others $v$. the Netherlands. European Court of Human Rights. Judgment of June 8, 1976. App. No. 5100/71, 5101/71, 5102/71, 5354/72, 5370/72. Series A, no 22 //

http://hudoc.echr.coe.int/sites/eng/pages/search.aspx?i=001-57479.

13. Golder v. UK. European Court of Human Rights. Judgment of February 21, 1975. App. No. 4451/70 //

http://hudoc.echr.coe.int/sites/eng/pages/search.aspx?i=001-57496.

14. Humphrey, J. P. "The revolution in International Law on Human Rights." Human Rights Law Journal 4 (1974-75): 203-220.

15. Humphrey, J. P. "The Universal Declaration of Human Rights: Its History, Impact and Juridical Character": 21-37. In: B. G. Ramcharan, ed. Human Rights:Thirty Years After the Universal Declaration. Dordrecht: Martinus Nijhoff, 1979.

16. Janis, Mark W., and Richard S. Kay. European Human Rights Law. Connecticut: University of Connecticut Law School Foundation Press, 1990.

17. J. J. v. Netherlands. European Court of Human Rights. Judgment of March 27, 1998. App. No. 9/1997/793/994 // http://hudoc.echr.coe.int/sites/eng/pages/search.aspx?i=001-58147.

18. Letsas, George. A Theory of Interpretation of the Convention on Human Rights. Oxford University Press, 2007. 
19. Manukijan, Vladimir I. Evropeiskii sud po pravam cheloveka: pravo, precedenti, komentarii. Nauchno-prakticheskoe posobie. Kiev: Istina, 2007 [in Russian].

20. O'Neill, Aidan. "Reform of Strasbourg Court: a modest proposal." UK Human Rights Blog // http://ukhumanrightsblog.com/2011/03/28/reform-ofstrasbourg-court-a-modest-proposal-aidan-oneill-qc/.

21. Oppenheim, L. International Law. $8^{\text {th }}$ ed. Lauterpacht, 1955.

22. Ryssdal, Rolv. "The Coming Age of the European Convention on Human Rights." European Human Rights Law Review 1 (1996): 18-30.

23. Shevchuk, Stanislav. Porivnialne precedentne pravo z prav liudini. Kyiv: Referat, 2002. [in Ukrainian].

24. Twenty-One Detained persons v. Germany. European Court of Human Rights. Decision of April 6, 1968. Collection 27, p. 97-116. 